\title{
Yields and the selected physicochemical properties of thermobitumen as an intermediate product of the pyrolysis of Kukersite oil shale
}

\author{
Hanna-Liina Astra $^{(a)}$, Tiina Albert ${ }^{(a)}$, Sepehr Mozaffari $^{(b)}$, Oliver \\ $J_{a ̈ r v i k}^{(a, b)}$, Alexey Yanchilin ${ }^{(a)}$, Sven Kamenev ${ }^{(b)}$, Selhan Karagöz ${ }^{(\mathrm{c})}$, \\ Vahur Oja $a^{(a, b) *}$
}

Received 21 January 2021, accepted 10 November 2021, available online 10 December 2021

(a) Department of Chemical Engineering, Tallinn University of Technology, Ehitajate tee 5, 19086 Tallinn, Estonia

(b) Department of Energy Technology, Tallinn University of Technology, Ehitajate tee 5, 19086 Tallinn, Estonia

(c) Department of Chemistry, Karabük University, 78050 Karabük, Turkey

\begin{abstract}
In the pyrolytic decomposition of kerogen, a macromolecular crosslinked material of oil shale, the formation of thermobitumen is often considered an important intermediate step in pyrolysis modelling. The authors' literature review indicated that information regarding the yield of thermobitumen from Kukersite oil shale was somewhat contradictory, and data on physicalthermodynamic properties, which is to be used in engineering calculations, was limited. Therefore the present work provides further information on thermobitumen yield levels and properties, along with empirical correlations, which serve to link together pyrolysis temperature, time, and/or selected properties (molecular weight, $H / C$, density, refractive index, and heat capacity). No information can be found on the last three properties for thermobitumens, derived from either Kukersite oil shale or other oil shale. The paper contributes to the topic by presenting information under conditions in which volatile pyrolytic products (oil and water) were removed from a pyrolysis system by an inert gas flow. So far, the formation of thermobitumen in Kukersite oil shale pyrolysis has been studied in either closed or open systems with no inert gas flow. To further generalise the results, the article also presents some comparisons with Green River formation oil shale thermobitumens, which were produced under similar conditions.
\end{abstract}

Keywords: thermobitumen, molecular weight, density, refractive index, hydrogen-carbon ratio, heat capacity.

\footnotetext{
* Corresponding author: e-mailvahur.keemteh@outlook.com

(C) 2021 Authors. This is an Open Access article distributed under the terms and conditions of the Creative Commons Attribution-NonCommercial 4.0 International License (http://creativecommons.org/licenses/by-nc/4.0/).
} 


\section{Introduction}

Oil shale, a solid fossil fuel, is a potentially important source of chemicals and oil due to the large amount of oil shale resources available. The world's oil shale resources are estimated to be equivalent to more than 2.9 trillion barrels of oil (one barrel $=0.159 \mathrm{~m}^{3}$ ), and these resources are distributed widely across the world [1]. To be able to produce the oil, the kerogen, or macro molecular organic component, in oil shale must be thermally decomposed in an inert environment [2]. In this process, depending upon the type of oil shale, the formation of thermobitumen, which can also be referred to as pyrolytic bitumen or a 'metaplast' in coal chemistry, is often considered as an important intermediate step of pyrolysis [2-5]. Consequently, the formation of thermobitumen has been included in pyrolytic schemes (multi-step pyrolytic schemes which show yields of major intermediate and final macro-products). Generally the decomposition step in converting kerogen to thermobitumen precedes the major formation of volatiles and char, in either sequential or simultaneous reaction schemes $[2,5,6]$. Moreover, the formation of the intermediate product thermobitumen is considered more significant for oil shales with high oil yields (as it contains the kerogen that softens during the pyrolysis process), such as Kukersite oil shale from Estonia or Green River formation oil shale from the USA [7-11]. For example, in relation to the industrial-scale retorting of Kukersite oil shale, the thermobitumen formation has historically caused operational problems due to its sticky character in slowpyrolysis fixed-bed gasifier type retorts. The formation of thermobitumen is also related to the phenomenon of thermal swelling [7]. Therefore the yields and properties of thermobitumen from Kukersite oil shale (such as the Estonian deposit or the Gdov deposit) have been of interest for the best part of the past century $[2,10,12-27]$.

A review of the literature shows that thermobitumen formation in the pyrolysis of Kukersite oil shale has been studied in either open systems (with the removal of volatiles that are driven by volatile formation itself, such as with a Fischer retort or similar systems [12-16], and no inert gas flowing through the material has been used), or closed systems (with no removal of volatiles such as, for instance, autoclaves $[17,18])$. While the practical purpose of the first approach is related to retort-based technological research, the second is more suitable for technological research on thermal dissolution [2]. These studies have been carried out over a wide range: utilising temperatures from $275^{\circ} \mathrm{C}[12]$ to $420{ }^{\circ} \mathrm{C}$ [13], and residence times from 0.08 hours (at $386{ }^{\circ} \mathrm{C}$ ) [14] to 456 hours (at $275{ }^{\circ} \mathrm{C}$ ) [12]. The yields and properties of the formed thermobitumen depend upon both the process conditions and the characteristics of kerogen, and also upon how thermobitumen has been operationally defined.

In general, thermobitumen is defined as an intermediate reaction product of kerogen pyrolytic decomposition that is non-volatile in its process condition and is soluble in organic solvents $[10,11]$. Very often it is the more specific 
definition that serves specifically to denote the solvent as being benzene, although extraction with other solvents such as methanol, acetone, and petroleum ether has also been used [12]. This definition of thermobitumen has historically been more or less followed by scientists but, in practice however, a specific thermobitumen is operationally definable, largely depending upon the purpose of the study. However, it could be emphasised here that the thermobitumen as an extraction product that had been obtained from the autoclave (a closed system) was often operationally defined as being a mixture of oil and thermobitumen, even down to including pyrolysis water.

By contrast, oil is defined as the organic pyrolytic decomposition product that is volatile in its process conditions and is condensable at room temperature. On that basis oil is volatile, and it can undergo secondary reactions at longer residence times if not removed rapidly. Therefore, an important factor in defining thermobitumen is whether those components that are vaporisable during pyrolysis (more specifically oil) are removed from the reactor and how fast this process occurs. In principle a complete oil removal with the shortest residence time can be obtained from the system by allowing inert gas to flow through the material that is undergoing pyrolysis. Therefore any thermobitumen that is obtained in this way more closely represents the definition 'based', or 'actual', thermobitumen. This approach has, for example, been used by Miknis et al. [11] in thermobitumen studies involving USA oil shales (western oil shales of the Green River formation such as the Colorado Anvil Points, Wyoming Tipton, and the Colorado Exxon-Colony, and Eastern oil shales such as those of Kentucky New Albany). Oil shale from the Green River deposit has a high oil yield and kerogen that softens during pyrolysis, as does Kukersite oil shale. On the other hand, New Albany oil shale (similarly to another Estonian oil shale - Dictyonema) has a low oil yield and kerogen that does not soften during pyrolysis, unlike Green River oil shale or Kukersite oil shale $[7,27,28]$.

Because Kukersite oil shale studies in relation to thermobitumen have only been conducted in closed systems or in open systems without an inert gas stream (such as with a Fischer retort or similar systems), this paper contributes to the topic by providing information in conditions under which volatiles were removed from the pyrolysis system by means of inert gas flow (with this flowing through the material that is undergoing pyrolysis). As the review showed that there was little information on the physical properties of thermobitumen in the available literature, our research team's interest in this topic was based on the physical properties that were seen as being important in chemical engineering calculations (especially those that are used to calculate other properties using thermodynamic property prediction approaches which are based on bulk properties). So far the most often measured characteristic parameters for Kukersite thermobitumens have been elemental composition in the first place (and/or the resultant $\mathrm{H} / \mathrm{C}$ ratio), followed by molecular weight [12-21]. In addition, there was also found some (not systematic) information regarding 
solvent fractionation $[12,22]$, spectroscopic data (infrared spectra [23, 24], nuclear magnetic resonance (NMR) spectra [24, 25], X-ray photoelectron spectra [24]), $\mathrm{OH}$ group content [12], and some information on the individual components [24-26]. The purpose of this study is to supplement the available information on average molecular weights and elemental composition, and to provide information on density, refractive index, and heat capacity that was not yet available. The work maps out the variations in these thermobitumen properties obtained at different pyrolysis temperatures and with different residence times, and provides easy-to-use empirical equations when it comes to determining these properties.

\section{Experimental}

\subsection{Oil shale sample}

Thermobitumens were produced from the freshly ground Estonian Kukersite oil shale sample with a particle size between 0.315 and $0.8 \mathrm{~mm}$ (the choice was based on experimental concerns such as pressure drop, uniform flow over the cross-sectional area, etc.) and an average organic content of $23.2 \%$, with a variation of $2 \%$ in the test samples. For confirmation, some subsequent comparative experiments were performed on another oil shale sample with the same particle size range, and these results were normalized to the original oil shale sample. The ultimate analysis for the oil shale with an organic content of $23.2 \%$ delivered the following results on a dry basis (wt $\%$ ): $51.94 \%$ ash, $21.36 \%$ carbon, and $1.59 \%$ hydrogen. As the carbonaceous $\mathrm{CO}_{2}$ content was $24.88 \mathrm{wt} \%$, the estimated carbon and hydrogen composition of the organic matter was $75.42 \mathrm{wt} \% \mathrm{C}$ and $9.36 \mathrm{wt} \% \mathrm{H}$ (with an atomic $\mathrm{H} / \mathrm{C}$ ratio of 1.49 ). Additional information about the structure and composition of Kukersite oil shale and the properties of the retort products can be found via the following references [27, 29-33]. It is important to note again that Kukersite oil shale has a high oil yield and contains kerogen, which softens thermally [6]. Exemplary yields of pyrolysis products from Fischer Assay retorting under standard conditions (at a temperature of $520{ }^{\circ} \mathrm{C}$ ) for Kukersite kerogen on a dry basis are as follows: $59.7 \mathrm{wt} \%$ oil, $6.1 \mathrm{wt} \%$ pyrogenous water, $12.7 \mathrm{wt} \%$ gas, and $21.5 \mathrm{wt} \%$ semicoke (char) [21]. For indication purposes, the Fischer Assay oil properties are reported with the following sample figures: a relative density of about 0.964 , with an $\mathrm{H} / \mathrm{C}$ of about 1.43 , and a molecular weight of about $230 \mathrm{~g} / \mathrm{mol}[27,30,31]$.

\subsection{Thermobitumen production}

Thermobitumens were produced from Kukersite oil shale by means of isothermal pyrolysis at temperatures of $340{ }^{\circ} \mathrm{C}, 380^{\circ} \mathrm{C}$, and $420^{\circ} \mathrm{C}$. A U-shaped reactor which had been formed from a stainless steel pipe $(9.4 \times 2.3 \mathrm{~mm})$ 
and Swagelok fittings with a total volume of about $30 \mathrm{ml}$ were inserted in a convection oven that was preheated to the required temperature (as listed above). In principle, the set-up has the same design as that used by Miknis et al. [11]. Therefore the drawing for this set-up is not specifically shown. The pyrolysis temperatures were measured using a K-type thermocouple (accuracy $\pm 0.5^{\circ} \mathrm{C}$ ), which was inserted from the nitrogen inlet zone to a depth of about $10 \mathrm{~cm}$ into the oil shale layer in the U-shaped reactor. Pyrolysis times were between 15 minutes to 16 hours, counted from the moment at which the sample temperature was no more than $5{ }^{\circ} \mathrm{C}$ lower than the oven temperature. Average heating-up rates were about $20-25^{\circ} \mathrm{C} / \mathrm{min}$ as it took an average of 13,16 or 18 minutes to heat up the reactor that had been inserted into the preheated oven, from room temperature to temperatures of $340{ }^{\circ} \mathrm{C}, 380{ }^{\circ} \mathrm{C}$ and $420^{\circ} \mathrm{C}$, respectively. The pyrolysis process was stopped by removing the reactor from the oven and quickly cooling it in a water bath. Nitrogen (with a purity level of $99.995 \%$ ), which was pre-heated in the same convective oven until it reached the pyrolysis temperature, was allowed to flow through the packed bed of oil shale particles at a flow rate of about $100 \mathrm{ml} / \mathrm{min}$ and served to carry away (out of the reactor) the pyrolysis gases, water and oil vapours that had formed.

\subsection{Collecting oil and pyrolysis water}

The pyrolysis water and oil vapours from the reactor were condensed using water cooling and were collected in a container that had been placed in ice water. The container was weighed before and after each experiment to be able to ascertain water and oil mass as produced during pyrolysis. To prepare the oil for characterisation (involving measurements of its molecular weight and elemental composition), the oil was separated from the water by means of centrifugal force.

\subsection{Solvent extraction of thermobitumen}

Thermobitumens were extracted from solid pyrolysis residues that had been removed from the reactor after pyrolysis, by means of a Soxhlet extraction with solvent tetrahydrofuran (THF, boiling point $66^{\circ} \mathrm{C}$ ). In the current work the stabilised tetrahydrofuran ( $99 \%$ pure, Lachner, Czech Republic) was used. The tetrahydrofuran was chosen as the solvent because preliminary experiments showed that, when compared to benzene and dichloromethane, tetrahydrofuran provided the highest thermobitumen yield. The extraction process was carried out until the solvent that passed through the sample had become colourless. This took between 36 and 60 hours. After extraction the solvent was removed from the thermobitumen solution by means of a vacuum rotary evaporator at a pressure of about $4 \mathrm{mmHg}$ (in a water bath at $95^{\circ} \mathrm{C}$ ). The collected thermobitumen was solid at room temperature. The completeness of 
solvent removal was evaluated by means of thermogravimetric measurements with a heating rate of $10^{\circ} \mathrm{C} / \mathrm{min}$ up to $300{ }^{\circ} \mathrm{C}$ under an inert gas environment.

\subsection{Determining the $\mathrm{H} / \mathrm{C}$ ratio}

The elemental composition ( $w t \%$ carbon and $w t \%$ hydrogen) of the thermobitumen and oil samples was determined using an Exeter Analytical model CE440 elemental analyser. From this information the atomic $\mathrm{H} / \mathrm{C}$ ratios were calculated. The oxygen content in $\mathrm{wt} \%$, more precisely oxygen along with smaller amounts of nitrogen and sulphur, was determined by subtracting the carbon and hydrogen contents from $100 \mathrm{wt} \%$.

\subsection{Determining the number average molecular weight}

The number average molecular weights were determined using two different vapour pressure osmometers: first an Osmomat 070 (Gonotec $\mathrm{GmbH}$, Germany), and later a Knauer K-7000 (Wissenschaftliche Gerätebau Dr Ing Herbert KNAUER GmbH, Germany). With both instruments pyridine was used as a solvent (99\% pure, Sigma-Aldrich). When using the Osmomat 070 and the Knauer K-7000, measurements were carried out at temperatures of $85{ }^{\circ} \mathrm{C}$ and $75^{\circ} \mathrm{C}$, respectively. The standard deviation of number average molecular weights was less than $5 \%$. However, for some thermobitumen samples, the standard deviation of the number average molecular weights was found to be higher, based on data measured by different devices over a one-year period. A more detailed description of the measurement and analysis methods that were used to ascertain the number average molecular weight, along with the calibration principles for the instrument, are given in an earlier article from this laboratory by Järvik and Oja [31].

\subsection{Measurement of the density and refractive index of thermobitumen}

The density and refractive index of the thermobitumen were measured using respectively a DMA 5000M density meter and an Abbemat HT refractometer (both Anton Paar GmbH, Austria). Because the thermobitumen samples were solid at room temperature, in order to measure their density and refractive index those samples were first dissolved in tetralin (anhydrous 99\% pure, Sigma-Aldrich). For the purpose of ensuring uniform mixing, the sample solvent mixture with its known concentration levels in a closed vial was kept at a temperature of $60{ }^{\circ} \mathrm{C}$ for several hours and was then placed in an ultrasonic bath for 20 minutes to aid the dissolution process. The mass fraction of thermobitumen used fell within the range of 20-30\%. Its density values (or at least provisional density values) were then calculated from the measured pre-prepared mixture density values using a defined mixing rule as shown below (Eq. (1)): 


$$
\rho_{t h}=\left[\frac{1}{\rho_{m} X_{t h}}-\frac{X_{t e}}{\rho_{t e} X_{t h}}\right]^{-1}
$$

where $\rho$ is density, $X$ is the mass fraction and the subscripts $t h$, te, and $m$ stand respectively for thermobitumen, tetraline, and the mixture. The level of application for this mixing rule was checked by first measuring the density of industrial heavy oil technical fraction (from Kukersite shale oil) and then comparing it to the density value that was calculated using the mixing rule for the heavy oil that had been dissolved in tetralin (with a mass fraction of $20-30 \%$ ). The application of the mixing rule provided an error margin in the heavy oil density readings less than $1 \%$. The provisional refractive index values for the thermobitumen were calculated from the mixture information using a defined mixing rule as shown in Equation (2):

$$
R I_{m}=Y_{t h} R I_{t h}+Y_{t e} R I_{t e}
$$

where $R I$ is the refractive index and $Y$ is the volume fraction, and subscripts are as previously defined.

\subsection{Measurement of the heat capacity of thermobitumen}

The specific heat capacity of thermobitumen $\left(c_{p}\right)$ was measured using a Netzsch 204 HP Phoenix differential scanning calorimeter (DSC) with a nitrogen flow of $40 \mathrm{ml} / \mathrm{min}$. For the purpose of carrying out these measurements, a sample of approximately $20 \mathrm{mg}$ of thermobitumen was loaded into a pre-weighed Al capsule, and the capsule was hermetically sealed. Before carrying out the measurement process the capsule and the sample were heated to approximately $70{ }^{\circ} \mathrm{C}$ in order to melt the thermobitumen and obtain a uniform contact between the sample and the capsule. Then the sample was kept at $30^{\circ} \mathrm{C}$ for 10 minutes, whereafter the specific heat capacity measurement was carried out by ramping up the temperature at $20^{\circ} \mathrm{C} / \mathrm{min}$ to as high as $200^{\circ} \mathrm{C}$. The specific heat capacity of the sample $(s)$ was calculated from the previously measured sapphire standard (st) signal $S, \mathrm{~mW} / \mathrm{mg}$, as follows:

$$
c_{p}(s)=c_{p}(s t) \frac{S(s)}{S(s t)}
$$

The validity of the $c_{p}$ measurement was confirmed by measuring the specific heat capacity of anthracene. The average deviation in the temperature range was between $40-180{ }^{\circ} \mathrm{C}$ which, when compared to the information given in the work by Goursot et al. [34], was below 5\%. 


\section{Results and discussion}

\subsection{Yield of kerogen decomposition products: thermobitumen and sum of oil and water}

Yields of thermobitumen and yields of volatile oil shale decomposition products - the sum of oil and water yields - which were obtained under the various pyrolysis temperature and time conditions that were included in the investigation, are summarised in Table 1 and Table 2, respectively. These yields are given on the basis of the dry organic content of the original oil shale (as the $\mathrm{wt} \%$ of organic matter), and were calculated using the average organic content of $23.2 \mathrm{wt} \%$. The changes in the isothermal yield of thermobitumen and in the total isothermal yield of thermobitumen, oil, and pyrolysis water as a function time of pyrolysis are illustrated graphically at a temperature of $340{ }^{\circ} \mathrm{C}$ in Figure 1 , at $380^{\circ} \mathrm{C}$ in Figure 2 and at $420^{\circ} \mathrm{C}$ in Figure 3. Information from selected literature on Kukersite oil shale, for both open and closed systems, is shown for comparison in these figures. The figures also show that, in general, the thermobitumen yields that were measured in the current work were lower than those given in earlier studies on open systems for Kuklersite oil shale. The lower thermobitumen yields can be explained by the difference in the experimental procedures being used for thermobitumen preparation. In this study, a flow of inert gas was sent through the reactor to ensure the immediate removal of vaporising compounds, and care was taken to evaporate the solvent as fully as possible from the thermobitumen-solvent mixture in the vacuum rotary evaporator.

The yield profiles follow the trends that have been reported for different oil shales [11]. The yield profile for thermobitumen, the reactive intermediate product, is best illustrated at the temperature of $380^{\circ} \mathrm{C}$ in Figure 2. This is the typical concentration profile for consecutive in-series irreversible reactions, during which there occurs the transformation of the parent material into an intermediate, and then the intermediate to the product. The figure shows the shape of a positive skew (skewed to the right) which, according to the most simplified reaction scheme, can be considered as having been caused by competition between the rate of formation of thermobitumen and the rate of conversion of thermobitumen into final macro-products, mostly into oil. For the full temperature-time range, the exact shape depends upon the relative strength of each competing reaction which underlies the transformation. The experiments that were carried out at a temperature of $380{ }^{\circ} \mathrm{C}$ show that the highest yield of thermobitumen was seen at a heating time of two hours. The maximum yield of thermobitumen, around $50 \%$ of organic matter at the temperature of $380^{\circ} \mathrm{C}$, is also the maximum thermobitumen yield to have been observed in this work. At $340^{\circ} \mathrm{C}$ (Fig. 1), due to the relatively low temperature, after a period of around 14 hours the maximum yield of thermobitumen is reached at about $25 \%$ of organic matter (at the conclusion of the tests, as 


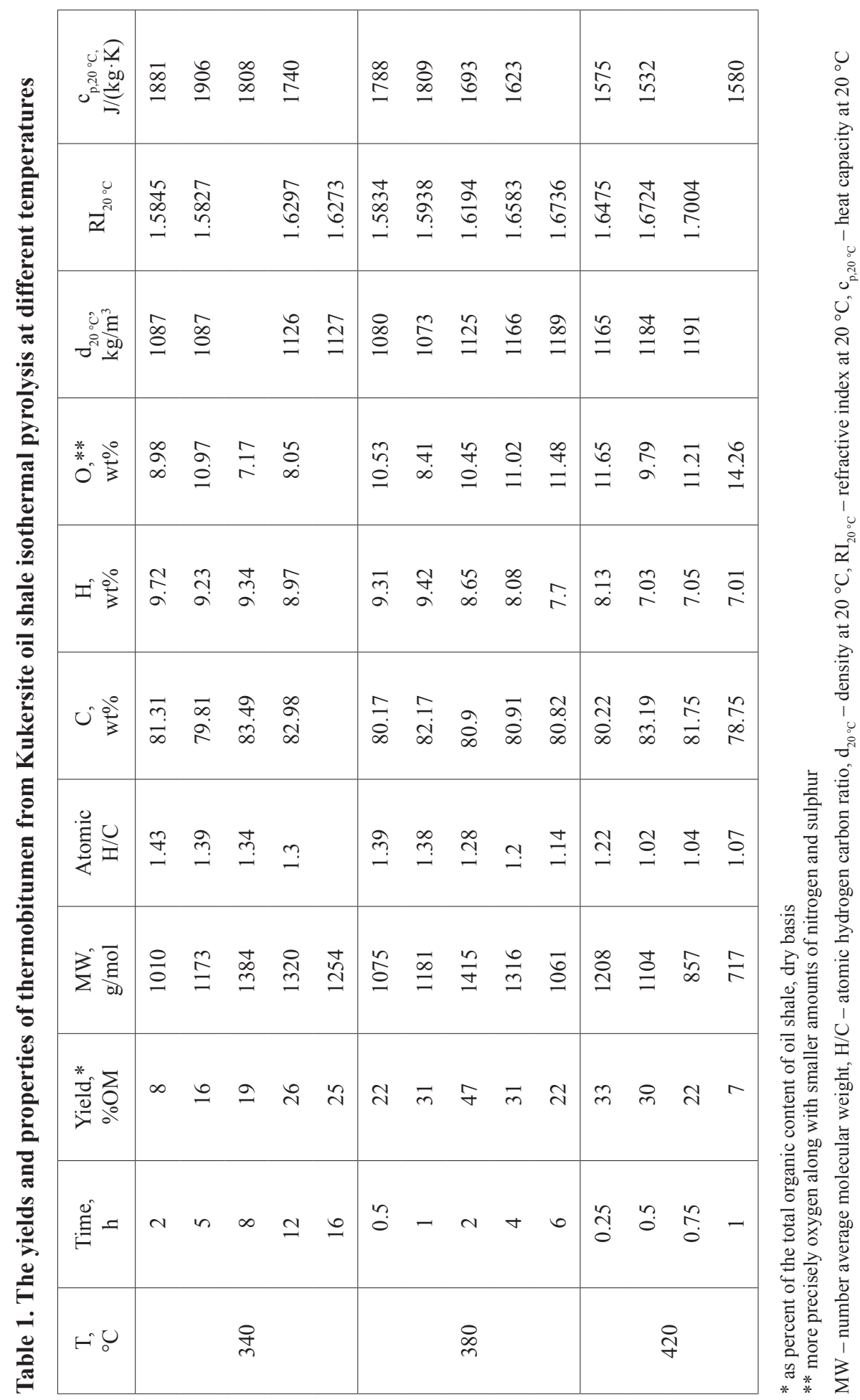


Table 2. Total yields of oil and pyrolysis water from Kukersite oil shale isothermal pyrolysis at different temperatures, and number average molecular weight, elemental composition and $\mathrm{H} / \mathrm{C}$ ratio of oil

\begin{tabular}{|c|c|c|c|c|c|c|c|}
\hline \multirow{2}{*}{$\begin{array}{l}\mathrm{T}, \\
{ }^{\circ} \mathrm{C}\end{array}$} & \multirow{2}{*}{$\begin{array}{l}\text { Time, } \\
\mathrm{h}\end{array}$} & \multirow{2}{*}{$\begin{array}{c}\text { Oil + water } \\
\text { Yield, } \% \mathrm{OM}^{* * *}\end{array}$} & \multicolumn{5}{|c|}{ Oil } \\
\hline & & & $\begin{array}{l}\mathrm{MW}, \\
\mathrm{g} / \mathrm{mol}\end{array}$ & $\begin{array}{c}\mathrm{C}, \\
\mathrm{wt} \%\end{array}$ & $\begin{array}{c}\mathrm{H}, \\
\mathrm{wt} \%\end{array}$ & $\begin{array}{l}\mathrm{O}, * * \\
\mathrm{wt} \%\end{array}$ & $\mathrm{H} / \mathrm{C}$ \\
\hline \multirow{5}{*}{340} & 2 & 8 & 188 & 79.46 & 10.5 & 10.03 & 1.59 \\
\hline & 5 & 15 & 196 & 79.86 & 10.34 & 9.8 & 1.55 \\
\hline & 8 & 21 & 190 & 79.69 & 10.32 & 9.99 & 1.55 \\
\hline & 12 & 25 & 186 & 79.79 & 10.3 & 9.92 & 1.55 \\
\hline & 16 & 40 & & & & & \\
\hline \multirow{5}{*}{380} & 0.5 & 14 & 178 & 79.91 & 10.59 & 9.51 & 1.59 \\
\hline & 1 & 19 & 180 & 80.32 & 10.91 & 8.77 & 1.63 \\
\hline & 2 & 28 & 180 & 80.62 & 10.7 & 8.69 & 1.59 \\
\hline & 4 & 44 & 200 & 80.94 & 10.32 & 8.75 & 1.53 \\
\hline & 6 & 56 & 199 & 81.63 & 10.4 & 7.98 & 1.53 \\
\hline \multirow{4}{*}{420} & 0.25 & 37 & 198 & 81.5 & 10.32 & 8.18 & 1.52 \\
\hline & 0.5 & $56^{*}$ & 182 & 81.23 & 10.7 & 8.08 & 1.58 \\
\hline & 0.75 & $45^{*}$ & 172 & 80.99 & 10.66 & 8.37 & 1.58 \\
\hline & 1 & 59 & 201 & 81.34 & 10.4 & 8.28 & 1.52 \\
\hline
\end{tabular}

* the total yield of oil and water can only increase over time, therefore, the lower yield at $0.75 \mathrm{~h}$ compared to that at $0.5 \mathrm{~h}$ is due to the experimental error

** more precisely oxygen along with smaller amounts of nitrogen and sulphur

$* * *$ as percent of the total organic content of oil shale, dry basis

the last points were measured at 12 and 16 hours). In experiments that were conducted at a temperature of $420{ }^{\circ} \mathrm{C}$ (Fig. 3), the processes described tend to occur in the shortest times. The maximum thermobitumen yield of about $35 \%$ of organic matter at $420{ }^{\circ} \mathrm{C}$ is reached at resident times corresponding to the start of the tests (the first point was measured at 15 minutes).

During the process of isothermal pyrolysis, the overall yield profile (the thermo-bitumen, oil, and water profile) increases with residence time, followed by stabilisation or a slight decrease in their yield before stabilization. An explanation of this yield trend can be found in the reference material by Miknis et al. [11]. In short, depending on the type of oil shale kerogen used, competing pyrolysis reactions (including the pathway through thermobitumen formation) resulted in different yield ratios for the final macroproducts (oil, gas, pyrolysis water, and char). The pyrolytic reactions of kerogens with high oil yields promote oil (the highest yielding product) formation, and low oil 


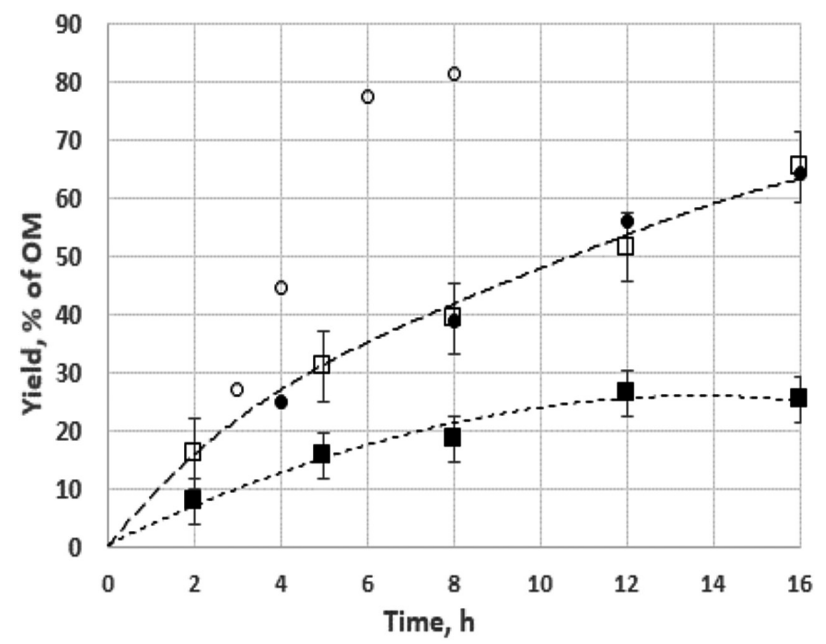

Fig. 1. The yield of thermobitumen ( $\square$ ) and the total yield of thermobitumen, oil, and water $(\square)$ produced during the isothermal pyrolysis of Kukersite oil shale as a function of pyrolysis time at a temperature of $340{ }^{\circ} \mathrm{C}$. Literature-based information for Kukersite oil shale at $340^{\circ} \mathrm{C} \mathrm{(O} \mathrm{open} \mathrm{system} \mathrm{[17];} \mathrm{\bullet} \mathrm{closed} \mathrm{system} \mathrm{[12])} \mathrm{is} \mathrm{shown}$ for comparison.

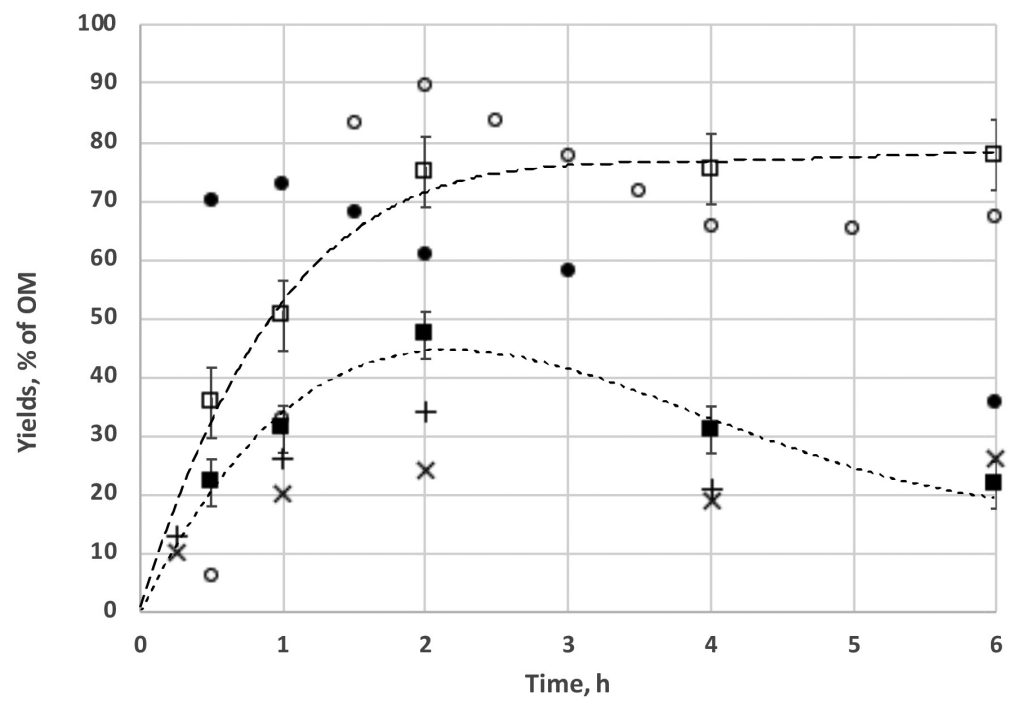

Fig. 2. The yield of thermobitumen ( $\square$ ) and the total yield of thermobitumen, oil, and water ( $\square$ ) produced during the isothermal pyrolysis of Kukersite oil shale as a function of pyrolysis time at a temperature of $380^{\circ} \mathrm{C}$. Literature-based information for Kukersite oil shale at $380^{\circ} \mathrm{C}$ ( $\circ$ open system [17]; • closed system [14]), and for Green River oil shale $\left(+\right.$ for $375^{\circ} \mathrm{C}[11]$; $\times$ for $394^{\circ} \mathrm{C}[12]$ ), is shown for comparison. 


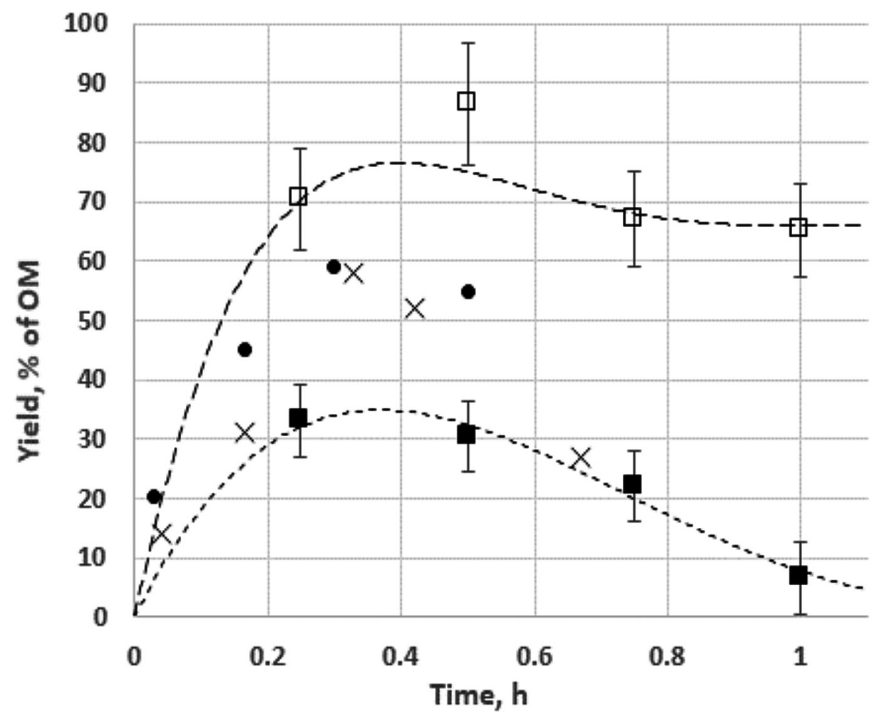

Fig. 3. The yield of thermobitumen ( $\mathbf{a})$ and the total yield of thermobitumen, oil, and water $(\square)$ produced during the isothermal pyrolysis of Kukersite oil shale as a function of pyrolysis time at a temperature of $420{ }^{\circ} \mathrm{C}$. Literature-based information for Kukersite oil shale at $420^{\circ} \mathrm{C}(\bullet$ closed system [10, 15]), and for Green River oil shale at $425^{\circ} \mathrm{C}(+)[11]$, is shown for comparison.

yield kerogens give more char and gas. In the case of Kukersite oil shale, it has been shown that the maximum oil yield is obtained at the point of complete decomposition of thermobitumen, which is about at $450{ }^{\circ} \mathrm{C}$ under slow heating rate conditions [16]. It can be seen from Table 2 that, at temperatures of $380{ }^{\circ} \mathrm{C}$ and $420{ }^{\circ} \mathrm{C}$, the total yield of oil and water reached was between $56-59 \%$ of organic matter, which is close to the oil yield obtained in retorting Kukersite oil shale in a Fischer retort (which produced about $60 \%$ of organic matter $[15,30])$. The proportion of pyrolysis water formed during decomposition of kerogen in the temperature range used in this work could be about $2-5 \mathrm{wt} \%$ of the organic content of dry oil shale [12, 15].

Figures 2 and 3 also compare thermobitumen yield information for Kukersite oil shale against that of Green River oil shale [11]. Experiments on both oil shales were carried out under conditions in which volatile pyrolytic products (oil and water) were removed from a pyrolysis system by means of an inert gas flow (one which was flowing through the material that was undergoing pyrolysis). Figures 2 and 3 indicate that thermobitumen yield curves were of similar shape. However, in Figure 2, at a temperature of about $380{ }^{\circ} \mathrm{C}$, the yield for Green River oil shale was lower than that of Kukersite oil shale (the maximum yield was lower by about 10-15 units, being expressed as a percentage of organic matter). In Figure 3, at a temperature of about $420{ }^{\circ} \mathrm{C}$, the yield for Green River oil shale was higher than that of Kukersite oil shale 
(the maximum yield was higher by about 20-25 units, being expressed as a percentage of organic matter). This indicated different rates of formation and/ or conversion of thermobitumen during the pyrolysis of these types of oil shale.

\subsection{Molecular weights and atomic $H / C$ ratios of oil accompanying thermobitumen formation}

Miknis et al. [11] have shown that, for a given oil shale, molecular weights and $\mathrm{H} / \mathrm{C}$ ratios for the oils released during the process of isothermal pyrolysis are essentially constant over the region of thermobitumen existence. This applies to oils associated with the formation and/or conversion of thermobitumen throughout the temperature-time history of the isothermal pyrolysis studied. The results of the current work, as presented in Table 2, show that these properties of pyrolysis oils from Kukersite oil shale also behave similarly, with the average molecular weight of oils being $188 \mathrm{~g} / \mathrm{mol}$ (within about $170-200 \mathrm{~g} / \mathrm{mol}$ ), and the average $\mathrm{H} / \mathrm{C}$ molar ratio being 1.56 (within about 1.52 and 1.63). These molecular weight values are somewhat lower and the $\mathrm{H} / \mathrm{C}$ ratios are somewhat higher than those usually obtained from Kukersite oil shale pyrolysis in a Fischer retort $[27,30]$. This is likely due to the lower pyrolysis temperatures obtained in the current study. When compared to the Green River oil shale oils, with an average molecular weight of $358 \mathrm{~g} / \mathrm{mol}$ and an average $\mathrm{H} / \mathrm{C}$ ratio of 1.71) as established by Miknis et al. [11], the respective average values of Kukersite oils in the current study were lower. The same trend could also be observed when comparing the corresponding Fischer assay oils [27, 30].

\subsection{The molecular weight of thermobitumen}

The number average molecular weight values for thermobitumens from Kukersite oil shale as measured in this work are tabulated in Table 1, and their pyrolysis temperature and time dependence are illustrated in Figures 4-6. Figures 4-6 suggest that the overall pattern of molecular weight change in thermobitumen under isothermal conditions over time forms a continual 'increasing to decreasing' dependence: the molecular weight increases, exceeds the maximum and then decreases. Therefore, at the temperature-time point at which thermobitumen is completely decomposed or vanished, its average molecular weight values should approach those of volatile oil. The Kukersite oil shale's oil molecular weight distribution curves, which come from various pyrolysis regimes, can be found in earlier articles [31, 35, 36].

Figures 4-5 show that the molecular weight values from a previous study by Kask [12] are for the most part twice as low as those measured in the current work. However, in a few cases some similarities can be seen in the molecular weight of some of the samples. Therefore, when considering the complexity of removing solvents completely, the lower molecular weight values measured 


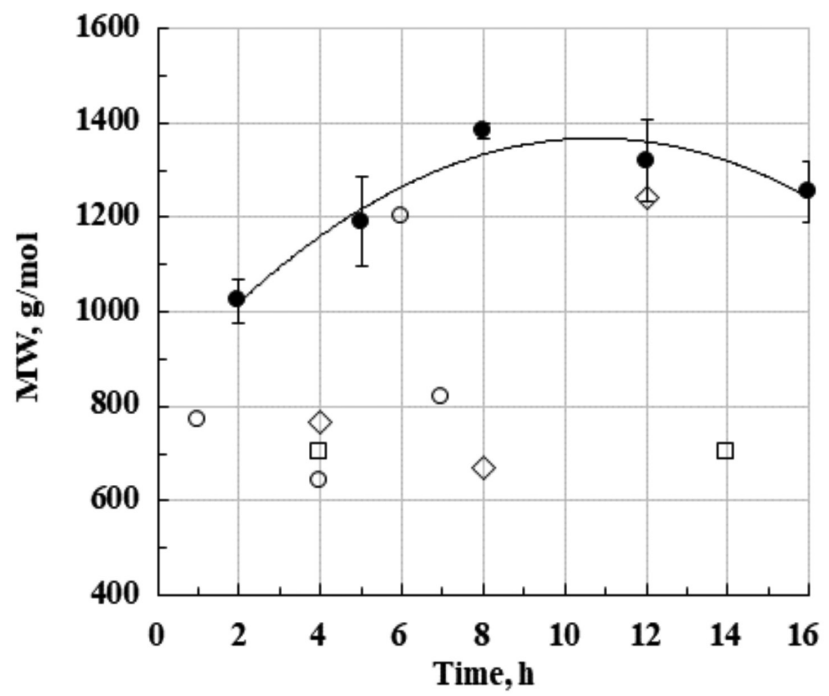

Fig. 4. Number average molecular weights (MW) for thermobitumens taken from the isothermal pyrolysis of Kukersite oil shale at $340{ }^{\circ} \mathrm{C}(\bullet$, this study) in comparison with earlier information (small reactor $360^{\circ} \mathrm{C}$ as $\circ$; small reactor $340{ }^{\circ} \mathrm{C}$ as $\diamond$; large reactor $360^{\circ} \mathrm{C}$ as $\left.\square\right)$ [12].

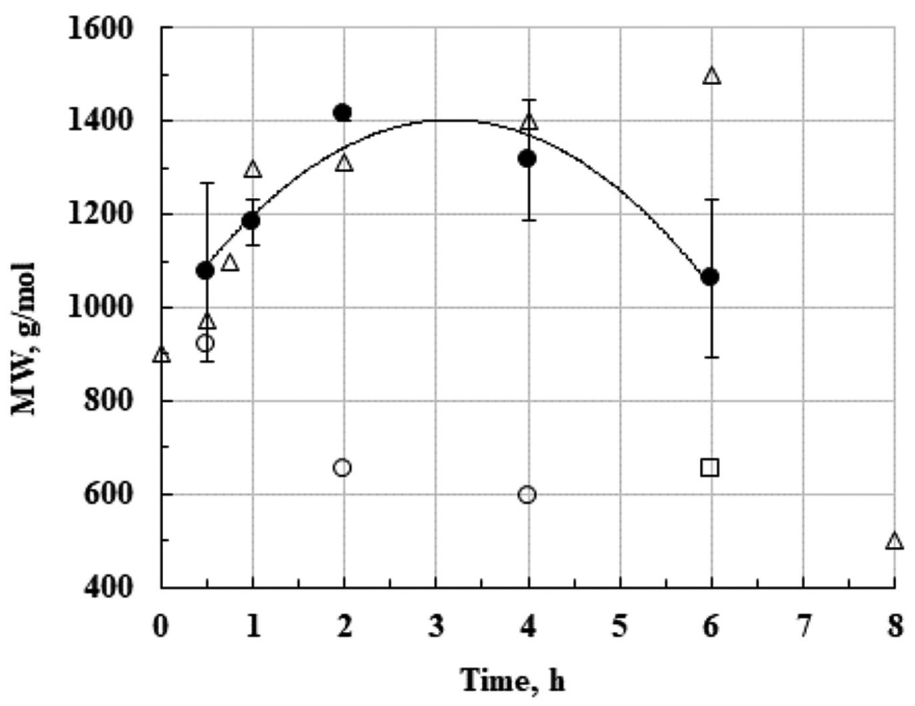

Fig. 5. Number average molecular weights (MW) for thermobitumens taken from the isothermal pyrolysis of Kukersite oil shale at $380{ }^{\circ} \mathrm{C}(\bullet$, this study) in comparison with earlier information at the same temperature (small reactor as $\circ$; large reactor as $\square)$ [12], and information on thermobitumen taken from Green River oil shale and obtained at $375^{\circ} \mathrm{C}(\Delta)[11]$. 


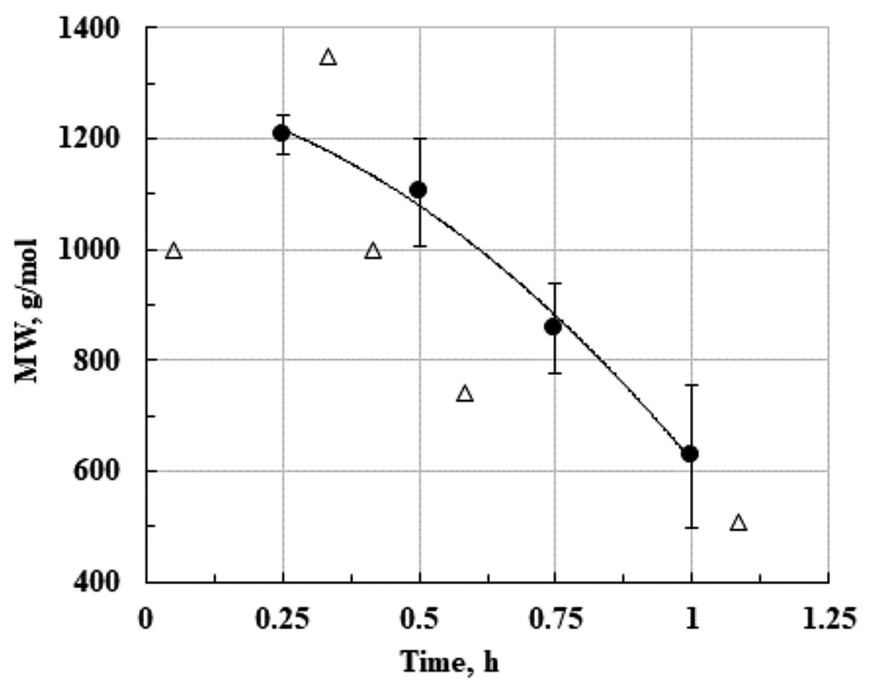

Fig. 6. Number average molecular weights (MW) for thermobitumens obtained from the pyrolysis of Kukersite oil shale at $420{ }^{\circ} \mathrm{C}(\bullet$, this study) in comparison with information on thermobitumen taken from Green River oil shale, obtained at $425{ }^{\circ} \mathrm{C}$ $(\Delta)[11]$

by Kask [12], which are given here for reference purposes, could have been caused by a portion of the solvent remaining in thermobitumen. For example, if a sample of thermobitumen has a molecular weight of $1300 \mathrm{~g} / \mathrm{mol}$, then in order to have a molecular weight of $700 \mathrm{~g} / \mathrm{mol}$ it must contain about $50 \mathrm{~mol} \%$ or $5.5 \%$ by weight of benzene.

When compared to the Green River oil shale-based study by Miknis et al. [11], Figures 5-6 indicate analogous relationships between molecular weight and pyrolysis times during the isothermal processes studied. In Figure 5 it can be seen that most of the values that were obtained at different pyrolysis times match closely (with the exception of the six-hour and $380{ }^{\circ} \mathrm{C}$ point). In Figure 6 the difference in molecular weights is somewhat large (as a five degree temperature difference may be more significant at higher temperatures), but similar decreasing changes can be seen in the molecular weight of thermobitumen as a function of pyrolysis time.

\subsection{The $\mathrm{H} / \mathrm{C}$ ratio of thermobitumen}

$\mathrm{H} / \mathrm{C}$ ratio is a parameter that can be with today's capabilities determined relatively easily and quickly and with a high degree of accuracy for a collected thermobitumen sample. The carbon and hydrogen contents of Kukersite thermobitumens prepared for this work and the atomic $\mathrm{H} / \mathrm{C}$ ratio calculated are given in Table 1 . At temperatures of $340{ }^{\circ} \mathrm{C}$ and $380{ }^{\circ} \mathrm{C}$ the $\mathrm{H} / \mathrm{C}$ ratio shows a clearly decreasing trend over time, as a result of the simultaneous 
condensation and decomposition reactions and the vaporisation of the formed oil. A slight increase in the $\mathrm{H} / \mathrm{C}$ ratio over a period between 30 minutes and one hour during the $420{ }^{\circ} \mathrm{C}$ experiment, as seen in Table 1 , could also be an actual trend. As expressed by Aarna and Rikken [16], at every temperature the decomposition products of kerogen tend towards their most stable form, which causes the $\mathrm{H} / \mathrm{C}$ ratio to decrease. Kask [12] and Miknis et al. [37] were able to show this decreasing trend respectively in pyrolysis of Kukersite oil shale and of both Green River (Colorado) and New Albany oil shales. Miknis et al. [37] also found that the total mass of aromatic carbon in the oil and solid products that were formed during pyrolysis serves to reach its maximum level at about the same time as the thermobitumen yield reaches its maximum value and then remains constant after that.

$\mathrm{H} / \mathrm{C}$ ratio is also a characteristic parameter of a material that is used in different correlations for calculating other properties [38]. Therefore, from the results of the ongoing work, an easy-to-use empirical Equation (4) was derived to calculate the Kukersite oil shale thermal bitumen $\mathrm{H} / \mathrm{C}$ ratio as a function of pyrolysis temperature $(T)$ and time $(t)$ as follows (with an absolute average deviation of 0.05 units):

$$
H / C=3.354-5.336 \times 10^{-3} \times T\left[{ }^{\circ} \mathrm{C}\right]-2.404 \times 10^{-2} \times t[h] .
$$

A comparison with relevant measured $\mathrm{H} / \mathrm{C}$ values is given in Table 3 as a relative percentage difference. Equation (4) was also used to calculate the $\mathrm{H} / \mathrm{C}$ ratios for information that was taken from reference sources [11, 37], along with thermobitumens from the pyrolysis of Green River (Colorado) and New Albany oil shales. The best results were obtained for New Albany thermobitumen at temperatures of $375{ }^{\circ} \mathrm{C}$ and $400{ }^{\circ} \mathrm{C}$, with an absolute average deviation of 0.12 units. In fact, the equation that was developed based on the information from this study on Kukersite oil shale provided more accurate results than the equation that was developed directly from pyrolysis information for New Albany thermobitumen reported by Miknis et al. [37]. For thermobitumens from Green River oil shale Equation (4) provided scattered results and $\mathrm{H} / \mathrm{C}$ values that were about 0.25 units less than the actual values. Therefore the following exemplary equation was derived from the reference information [11] for Green River oil shale:

$$
H / C=2.681-3.122 \times 10^{-3} \times T\left[{ }^{\circ} \mathrm{C}\right]-1.027 \times 10^{-3} \times t[h] .
$$

\subsection{The density, refractive index and heat capacity of thermobitumen}

The density, refractive index, and heat capacity of thermobitumen, all at $20^{\circ} \mathrm{C}$, are given in Table 1 . The thermobitumen heat capacity at $20^{\circ} \mathrm{C}$ remains in the range of $1532-1906 \mathrm{~J} /(\mathrm{kg} \cdot \mathrm{K})$, being respectively about $350-750 \mathrm{~J} /(\mathrm{kg} \cdot \mathrm{K})$ larger than the heat capacity of Kukersite oil shale kerogen. The Kukersite 
kerogen (with a $91 \%$ organic content) has a heat capacity of $1150 \mathrm{~J} /(\mathrm{kg} \cdot \mathrm{K})$ [39]. Thermobitumen's density values at $20{ }^{\circ} \mathrm{C}$ fall between 1073 and 1191 $\mathrm{kg} / \mathrm{m}^{3}$. The density of Kukersite oil shale kerogen is at $1100 \mathrm{~kg} / \mathrm{m}^{3}$ [39]. Figure 7 shows density and heat capacity as a function of the $\mathrm{H} / \mathrm{C}$ ratio of thermobitumen. The figure reveals that as the $\mathrm{H} / \mathrm{C}$ ratio increases, i.e. as the aromatic levels decrease, the density decreases and the heat capacity increases. Figure 7 also shows that there is a rough linear dependence between density (and therefore refractive index) and heat capacity on the $\mathrm{H} / \mathrm{C}$ ratio, and therefore the density $\left(\mathrm{d}_{20^{\circ} \mathrm{C}}\right)$, refractive index $\left(\mathrm{RI}_{20^{\circ} \mathrm{C}}\right)$, and heat capacity $\left(\mathrm{C}_{\mathrm{p}, 20^{\circ} \mathrm{C}}\right)$ can be approximately calculated. For calculations taken from the H/C ratio of thermobitumen, the following Equations (6)-(8) were derived:

$$
\begin{aligned}
& d_{20^{\circ} \mathrm{C}}\left[\mathrm{kg} / \mathrm{m}^{3}\right]=-300.9 \times(H / C)+1510.5, \\
& R I_{20^{\circ} \mathrm{C}}=2.0075-0.29901 \times(H / C), \\
& c_{p, 20^{\circ} \mathrm{C}}[\mathrm{J} / \mathrm{kgK}]=610.9+871.9 \times(H / C) .
\end{aligned}
$$

The evaluation of the performance of these equations against the corresponding measured values is given in Table 3 as a relative percentage difference. The average absolute deviations between the predicted and actual values of refractive index and heat capacity are 0.01 and $41 \mathrm{~J} /(\mathrm{kg} \cdot \mathrm{K})$, respectively. When comparing the predictions for density from Equation (6) with the results measured in the current work, the average absolute deviation

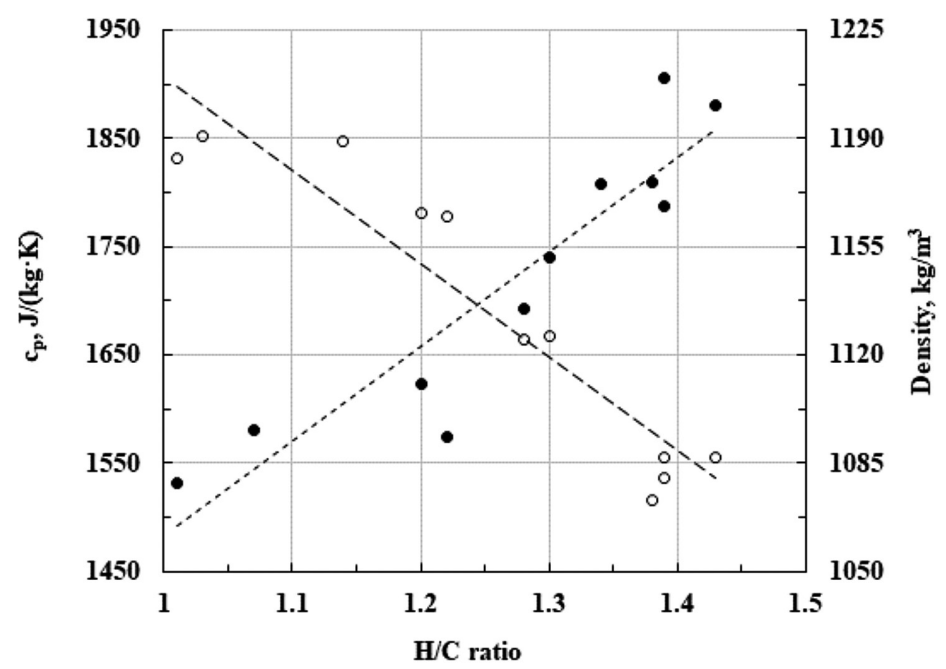

Fig. 7. Densities at $20{ }^{\circ} \mathrm{C}(\circ)$ and heat capacities at $20{ }^{\circ} \mathrm{C}(\bullet)$ for thermobitumen taken from Kukersite oil shale isothermal pyrolysis as a function of the $\mathrm{H} / \mathrm{C}$ ratio (information from this study). 
Table 3. Relative percentage difference between the measured properties and the results calculated with easy-to-use empirical equations derived from them*

\begin{tabular}{|c|c|c|c|c|c|c|}
\hline \multirow[b]{2}{*}{$\begin{array}{l}\mathrm{T}, \\
{ }^{\circ} \mathrm{C}\end{array}$} & \multirow[b]{2}{*}{$\begin{array}{c}\text { Time, } \\
\mathrm{h}\end{array}$} & \multicolumn{5}{|c|}{ Relative percentage difference } \\
\hline & & $\begin{array}{c}\mathrm{H} / \mathrm{C}, \\
\text { Eq. (4), \% }\end{array}$ & $\begin{array}{c}\mathrm{d}_{20^{\circ} \mathrm{C}}, \\
\text { Eq. (6), \% }\end{array}$ & $\begin{array}{l}\mathrm{RI}_{20^{\circ} \mathrm{C}^{\prime}} \\
\text { Eq. ( } 7), \%\end{array}$ & $\begin{array}{c}c_{p, 20^{\circ} \mathrm{C}}, \\
\text { Eq. }(8), \%\end{array}$ & $\begin{array}{c}\mathrm{c}_{\mathrm{p}, 20^{\circ} \mathrm{C}}, \\
\text { Eq. }(10), \%\end{array}$ \\
\hline \multirow{5}{*}{340} & 2 & -4.3 & 0.6 & 0.3 & 1.2 & 0.2 \\
\hline & 5 & -2.1 & -0.5 & -0.6 & 4.4 & 4.1 \\
\hline & 8 & -0.6 & & & 1.6 & 2.5 \\
\hline & 12 & 3.7 & 0.6 & 0.7 & -0.3 & 0.4 \\
\hline & 16 & & & & & \\
\hline \multirow{5}{*}{380} & 0.5 & 5.4 & -1.1 & -0.5 & -1.9 & -2.7 \\
\hline & 1 & 5.6 & -2.1 & -0.1 & -0.3 & -0.5 \\
\hline & 2 & 0.1 & 0.0 & -0.3 & -2.0 & -0.8 \\
\hline & 4 & -2.5 & 1.4 & 0.6 & -2.1 & -1.2 \\
\hline & 6 & -3.7 & 1.8 & 0.4 & & \\
\hline \multirow{4}{*}{420} & 0.25 & 9.3 & 1.9 & 0.3 & -6.3 & -6.0 \\
\hline & 0.5 & -7.9 & $-1,7$ & -1.8 & 2.1 & 2.3 \\
\hline & 0.75 & -5.3 & -0.6 & 0.2 & & \\
\hline & 1 & -1.8 & & & 2.3 & 0.3 \\
\hline
\end{tabular}

* The properties are given in the Table by temperature and time.

was about $13 \mathrm{~kg} / \mathrm{m}^{3}$ by using the measured $\mathrm{H} / \mathrm{C}$ ratio, and $26 \mathrm{~kg} / \mathrm{m}^{3}$ when using the $\mathrm{H} / \mathrm{C}$ ratio calculated from Equation (4). The relationship between density and $\mathrm{H} / \mathrm{C}$ ratio for Kukersite thermobitumen can also be approximately calculated from a linear equation that is based on information taken from the Crude Oil Assay database [40] as:

$$
d_{15^{\circ} \mathrm{C}}\left[\mathrm{kg} / \mathrm{m}^{3}\right]=1636-428 \times\left(\frac{H}{\mathrm{C}}\right) \text {. }
$$

The average absolute deviation between the measured and calculated densities was $38 \mathrm{~kg} / \mathrm{m}^{3}$ when using Equation (9). For heat capacity, a slightly better fit with experimental information (with an absolute average deviation of about $34 \mathrm{~J} / \mathrm{kg} \cdot \mathrm{K}$ ) can be achieved by a two-parameter equation in which the heat capacity of thermobitumen is predicted as a function of $\mathrm{H} / \mathrm{C}$ ratio and MW (kg/kmol):

$$
C_{p 20^{\circ} \mathrm{C}}[\mathrm{J} / \mathrm{kgK}]=663+910.2 \times(H / C)-0.086 \times M W .
$$


A comparison with relevant measured values is given in Table 3 as a relative percentage difference. Applying this equation means that molecular weight has been measured, which is a time-consuming measurement and is often carried out with quite high levels of uncertainty. However, analogous regression equations for calculating the refractive index $\left(\mathrm{RI}_{20^{\circ} \mathrm{C}}\right)$ or density $\left(\mathrm{d}_{20^{\circ} \mathrm{C}}\right)$ of Kukersite oil shale thermobitumen showed no useful level improvement in performance.

\section{Conclusions}

This paper has presented information and trends on yields and the selected physical-thermodynamic properties of thermobitumen, an intermediate product of pyrolytic decomposition, from Kukersite oil shale isothermal pyrolysis at three temperatures: $340^{\circ} \mathrm{C}, 380^{\circ} \mathrm{C}$ and $420^{\circ} \mathrm{C}$. Our literature review showed that although the yields and characteristics of thermobitumen extracted from Estonian Kukersite oil shale have been of interest for around a century, the topic still required further investigation. This study has contributed to this topic by investigating the process of thermobitumen formation under conditions in which volatile - and at room temperature condensable - pyrolytic products (oil and water) are removed from a pyrolysis system by means of an inert gas, which is flowing through the material undergoing pyrolysis. Care was also taken to remove the solvent, which was used to dissolve the thermobitumen from the pyrolysis residues, from the thermobitumen-solvent mixture as completely as possible. When compared to information that is available in the literature on earlier Kukersite oil shale tests, the yield of thermobitumen in this study was seen to be lower and the molecular weight higher.

By utilising the characteristic properties of thermobitumen, this work was able to ascertain measurements of the $\mathrm{H} / \mathrm{C}$ ratio, average molecular weight, density at $20{ }^{\circ} \mathrm{C}$, refractive index at $20{ }^{\circ} \mathrm{C}$ and heat capacity at $20{ }^{\circ} \mathrm{C}$. The first two of these were the parameters that were commonly used to describe thermobitumen (with the $\mathrm{H} / \mathrm{C}$ ratio being more commonly used as it is easily quantifiable), but no previous information was found for the latter three, whether Kukersite or any other oil shale. Therefore empirical correlations were derived to be able to calculate the last three parameters from the $\mathrm{H} / \mathrm{C}$ ratio (with average absolute deviations of $13 \mathrm{~kg} / \mathrm{m}^{3}, 0.01$, and $34 \mathrm{~J} / \mathrm{kg} \cdot \mathrm{K}$, respectively). In addition, an empirical correlation was also presented in this paper to determine the $\mathrm{H} / \mathrm{C}$ ratio from the temperature and time of pyrolysis. 


\section{Acknowledgements}

Support for the study was provided by the National R\&D program "Energy" under the Project AR10129 "Examination of the Thermodynamic Properties of Relevance to the Future of the Oil Shale Industry" (P.I. V. Oja). The authors also acknowledge earlier financial supports provided by the Estonian Ministry of Education and Research, under target financing SF0140022s10 (P.I. V. Oja), and under the Estonian Science Foundation Grants 9297, 7222 and 5632 (P.I. V. Oja). The authors are very grateful to Einart Lindaru, Ilme Rohtla, Dr. Rivo Rannaveski, Dr. Zachariah S. Baird, Dr. Natalja Savest and Dr. Jelena Hruljova for their helpful advice, and for helping with thermobitumen characterization measurements or editorial comments.

\section{REFERENCES}

1. Dyni, J. R. Geology and resources of some world oil-shale deposits. Oil Shale, 2003, 20(3), 193-252.

2. Oja, V., Suuberg, E. M. Oil shale processing, chemistry and technology. In: Encyclopedia of Sustainability Science and Technology (Meyers, R. A., ed.). Springer, New York, 2012, 1-38.

3. Oja, V. Is it time to improve the status of oil shale science? Oil Shale, 2007, 24(2), 97-99.

4. Smith, K. L., Smoot, L. D., Fletcher, T. H., Pugmire, R. J. The Structure and Reaction Processes of Coal. Plenum Press, New York, 1994.

5. Burnham, A. K. Global Chemical Kinetics of Fossil Fuels: How to Model Maturation and Pyrolysis. Springer, 2017.

6. Burnham, A. K., Braun, R. L., Coburn, T. T., Sandvik, E. I., Curry, D. J., Schmidt, B. J., Noble, R. A. An appropriate kinetic model for well-preserved algal kerogens. Energy Fuels, 1996, 10(1), 49-59.

7. Savest, N., Hruljova, J., Oja, V. Characterization of thermally pretreated kukersite oil shale using the solvent-swelling technique. Energy Fuels, 2009, 23(12), 5972-5977.

8. Oja, V., Yanchilin, A., Kan, T., Strezov, V. Thermo-swelling behavior of Kukersite oil shale: Commercial grade oil shale compared to its kerogen. J. Therm. Anal. Cal., 2015, 119, 1163-1169.

9. Oja, V., Elenurm, A., Rohtla, I., Tali, E., Tearo, E., Yanchilin, A. Comparison of oil shales from different deposits: oil shale pyrolysis and co-pyrolysis with ash. Oil Shale, 2007, 24(2), 101-108.

10. Zaidentsal, A. L., Soone, J. H., Muoni, R. T. Yields and properties of thermal bitumen obtained from combustible shale. Solid Fuel Chem., 2008, 42, 74-79.

11. Miknis, F. P., Turner, T. F., Berdan, G. L., Conn, P. J. Formation of soluble products from thermal decomposition of Colorado and Kentucky oil shales. Energy Fuels, 1987,1(6), 477-483. 
12. Kask, K. A. About bituminization of kerogen of oil shale-kukersite. Report I. Transactions of Tallinn Polytechnic Institute, Series A, 1955, No. 63, 51-64 (in Russian).

13. Gubergrits, M. Y. Thermal Destruction of Shale-Kukersite. Valgus, Tallinn, 1966 (in Russian).

14. Schulman, A. I. Investigation of Bituminizing Process of Shale Organic Concentrate. PhD Thesis. Leningrad, VNIINeftchim, 1968 (in Russian).

15. Lippmaa, E. Study of thermal decomposition of Estonian oil shale. Transactions of Tallinn Polytechnic Institute, Series A, 1958, No. 9, 39-45 (in Russian).

16. Aarna, A. Ya., Rikken, Yu. T. About the mechanism of low-temperature decomposition of kukersite oil shale. Transactions of Tallinn Polytechnic Institute, Series A, 1958, No. 97, 53-67 (in Russian).

17. Tiikma, L., Zaidentsal, A., Tensorer, M. Formation of thermobitumen from oil shale by low-temperature pyrolysis in an autoclave. Oil Shale, 2007, 24(4), 535546.

18. Karavayev, N. M., Wener, I. M. About thermobitum of Gdov oil shale. Transactions of the Institute of Goryuchih Iskopayemyh, Academy of Sciences of USSR. 1950, 2, 285-295 (in Russian).

19. Luts, K. Der Estländische Brennschiefer-Kukersit, seine Chemie, Technologie und Analyse. Revaler Buchverlag G.M.B.H., Reval, 1934 (in German).

20. Aarna, A. Y. Dynamic of separation of volatile products at thermal destruction of oil shale. Transactions of Tallinn Polytechnic Institute, Series A, 1955, No. 63, 65-81 (in Russian).

21. Kask, K. A., Mihkelson, V. J. The chemical composition of thermobitumen of kukersite oil shale. Transactions of Tallinn Polytechnic Institute, Series A, 1958, No. 97. 68-84 (in Russian).

22. Broi-Karre, G., Proskuryakov, V. Investigation of low-temperature destruction of Gdov oil shale concentrate by infrared spectroscopy. J. Appl. Chem., 1966, 39(5), 1214-1216 (in Russian).

23. Aarna, A., Alev, M. Investigation of low-temperature destruction of kukersite shale by infrared spectroscopy. Transactions of Tallinn Polytechnic Institute, Series A, 1964, No. 210, 3-14 (in Russian).

24. Shi, J., Ma, Y., Li, S., Wu, J., Zhu, Y., Teng, J. Characteristics of Estonian oil shale kerogen and its pyrolysates with thermal bitumen as a pyrolytic intermediate. Energy Fuels, 2017, 31(5), 4808-4816.

25. Lille, Ü., Pehk, T., Purre, T., Bitter, L. Examination of the structure of heavy shale oil by means of NMR-spectroscopy. Proc. Acad. Sci. ESSR. Chem., 1973, 22(1), 17-25 (in Russian with English summary).

26. Akalin, E., Kim, Y.-M., Alper, K., Oja, V., Tekin, K., Durukan, I., Siddiqui, M. Z., Karagöz, S. Co-hydrothermal liquefaction of lignocellulosic biomass with Kukersite oil shale. Energy Fuels, 2019, 33(8), 7424-7435.

27. Urov, K., Sumberg, A. Characteristics of oil shales and shale-like rocks of known deposits and outcrops. Oil Shale, 1999, 16(3 SPECIAL: Monograph), 1-64.

28. Kilk, K., Savest, N., Yanchilin, A., Kellogg, D. S., Oja, V. Solvent swelling 
of Dictyonema oil shale: Low temperature heat-treatment caused changes in swelling extent. J. Anal. Appl. Pyrol., 2010, 89(2), 261-264.

29. Lille, Ü., Heinmaa, I., Pehk. T. Molecular model of Estonian kukersite kerogen evaluated by ${ }^{13} \mathrm{C}$ MAS NMR spectra. Fuel, 2003, 82(7), 799-804.

30. Elenurm, A., Oja, V., Tali, E., Tearo, E., Yanchilin, A. Thermal processing of dictyonema argillite and kukersite oil shale: Transformation and distribution of sulfur compounds in pilot-scale Galoter process. Oil Shale, 2008, 25(3), 328-334.

31. Järvik, O., Oja, V. Molecular weight distributions and average molecular weights of pyrolysis oils from oil shales: Literature data and measurements by size exclusion chromatography (SEC) and atmospheric solids analysis probe mass spectroscopy (ASAP MS) for oils from four different deposits. Energy Fuels, 2017, 31(1), 328-339.

32. Aarna, A., Paluoja, V. Determination of hydroxyl groups in shale oil by the acetylation method. In: Analytical Methods for Oil Shale and Oil Shale Products. Tallinn, Estonia, 1961, 23-26 (in Russian).

33. Siitsman, C., Oja, V. Extension of the DSC method to measuring vapor pressures of narrow boiling range oil cuts. Thermochim. Acta, 2015, 622, 31-37.

34. Goursot, P., Girdhar, H. L., Westrum Jr., E. F. Thermodynamics of polynuclear aromatic molecules. III. Heat capacities and enthalpies of fusion of anthracene. $J$. Phys. Chem., 1970, 74(12), 2538-2541.

35. Oja, V. Examination of molecular weight distributions of primary pyrolysis oils from three different oil shales via direct pyrolysis Field Ionization Spectrometry. Fuel, 2015, 159, 759-765.

36. Oja, V. Characterization of tars from Estonian Kukersite oil shale based on their volatility. J. Anal. Appl. Pyrol., 2005, 74(1-2), 55-60.

37. Miknis, F. P., Conn, P. J., Turner, T. F., Berdan, G. L. Isothermal Decomposition of New Albany Shale From Kentucky. Work Performed Under Cooperative Agreement DE-FC21-83FE60177, Laramie, Wyoming, 1985.

38. Riazi, M. R. Characterization and Properties of Petroleum Fractions. ASTM International, 2005.

39. Savest, N., Oja, V. Heat capacity of kukersite shale oil: Literature overview. Oil Shale, 2013, 30(2), 184-192.

40. Speight, J. G. Crude Oil Assay Database - Knovel. Online version 2014. http:// app.knovel.com/hotlink/toc/id:kpCOAD0005/crude-oil-assay-database/crudeoil-assay-database (accessed Feb 25, 2016). 